\title{
Integration as Disintegration. Some Remarks on the Romanian Case viewed by Emil Cioran
}

\section{Ovidiu PECICAN}

\begin{abstract}
The early writings of Emil Cioran, belonging to the years 1930, deal with the problem of the destiny of Romania. The rethinking and the reshaping of the country is configured by the young philosopher in the frame of the plans for disintegrating the old Europe in the views of a new, imperialist, integration of it. To interpret this tendency only taking into account the increasing totalitarian Europe of the 30es is not enough. The present analysis discovers other Romanian political tendencies in the same direction.
\end{abstract}

Keywords: Emil Cioran, Romania, integration, disintegration, Bismarck, Carol I, fascism

What could integration and of course, its reverse disintegration, mean for a young philosophy student and then to the temporary professor, temporary winner of a grant, from the inter-war period, who was passionate about the meditation on small and great cultures, on the western decline described by Ostwald Spengler, and on the lack of destiny of his own people? Whatever the answer to this question might be, the reference to the well-known philosopher of culture who wrote the successfull work Der Untergang des Abendlandes (1918, 1922-1923) ${ }^{1}$ is compulsory, because it offers the framework for the use - and the abuse - of the terms mentioned in the book of young Emil Cioran Romania's metanoia (written in 1935-1936, published in 1936). In this book, there is indeed not just more than one way of using the concepts of "integration" and "disintegration", but also an oxymoronic vision on them; a tensional, a contrasting vision. Actually, Emil Cioran conceives, paradoxically, the integration as a disintegration, a non-history

1 The Decline of the West (German: Der Untergang des Abendlandes), or The Downfall of the Occident, is a two-volume work by Oswald Spengler, the first volume of which was published in the summer of 1918. Spengler revised this volume in 1922 and published the second, subtitled Perspectives of World History, in 1923.

The book introduces itself as a 'Copernican overturning' and rejects the Euro-centric view of history, especially the division of history into the linear "ancient-medieval-modern" rubric. [1] According to Spengler the meaningful units for history are not epochs, but whole cultures which evolve as organisms. He acknowledges eight high cultures: Babylonian, Egyptian, Chinese, Indian, Mexican (Mayan/Aztec), Classical (Greek/Roman), Arabian, Western or "European-American". Cultures have a limited lifespan of some thousand years. The final stage of each culture is, in his word use, a 'civilization'. /.../

According to the theory, the Western world is actually ending and we are witnessing the last season - "winter time" - of the Faustian civilization. In Spengler's depiction, Western Man is a proud but tragic figure, for while he strives and creates, he secretly knows the actual goal will never be reached." (wikipedia, at: http://en.wikipedia.org/wiki/The_Decline_of_the_West) 
- as the famous thinking of Lucian Blaga reflected the historical vacuum from the Romanians destiny -, but also as a desertion from the historical and metaphysical mission that the Romanian people has to build or could build. Because the question is the following: if it really has the above mentioned mission, why doesn't it put it to work, following it scrupulously over a longer period of time? And if it doesn't, why doesn't it rise to the level of such a mission, as other people? Cioran thinks that the keeping into discretion, in an historical anonimity with no extraordinary facts, such as the great territorial conquests, or the great projects with long road traces, in other words the normal, average day-by-day organic development is the sure sign, on one hand, of the filution of the substance of a people, and on the other hand, the main symptom of a vocational castration, of a certain weakness in front of its mission. Such people will not acceed to edify a great civilisation, vanishing, step by step, from history.

Here are two of the important influences active in Cioran's thinking: the way Spengler conceives human civilisations and the way Lucian Blaga speaks about the mioritic space - namely, the metaphisical projection of the Romanian cultural relationship with the space of his own culture -, an opaque space, decayed from history, vague and ambiguous, which didn't let the traces of any capacity typical of a great culture able to give birth to an original civilisation.

Cioran's integration doesn't mean only the coming back to history and the insertion into the great history. For these were symptomatic, at that time, the approachement towards Hitler's Germany and, consequently, the entering into its gravity area, with the consequence of economic enslavement and of a strategic and military subordination to Berlin, for the longest part of the time of WW II. For the twenty four years old author, it also means the possibility of Romania's transformation into a unifying centre of the Balkans, more precisely into an inheriter of Constantinople ${ }^{2}$.

The idea is not as phantasmagoric as one could think. Its deepest roots can be traced back to the succession to the political power in the Byzantine Empire when, after 1204, Ioniță Caloian, the tzar of the Vlachs and the Bulgarians, tried it being eager to obtain for himself the basileus heritage. It can also be noticed the imperial and christian-orthodox ecumenic horizon in which some Romanian princes placed their approaches. I name, among those characters, Radu the Great - who brought Niphon, the Constantinopolitan patriarch, to Wallachia -, Neagoe Basarab, with

2 Ibidem, p. 230: “... fi-va România țara unificatoare a Balcanului, fi-va Bucureştiul Noul Constantinopol (subl. E.C.)?” / “... will Romania be the unifying country for the Balkan, will Bucharest be the New Constantinople?"/ Aspirațiile imperiale româneşti teoretizate de ideologii ortodoxişti ai Romei a IV-a oferă până astăzi cel mai flexibil şi mai adecvat model de înțelegere a unor fapte aparent disparate precum: daniile domnitorilor români la Muntele Athos, organizarea unui sinod cu ambiții ecumenice de către Vasile Lupu, la Iaşi (1642), implicarea României în războaiele balcanice şi Pacea de la Bucureşti (1913), acceptarea şi îndeplinirea de către România întregită a misiunii Antantei în Ungaria (1919), inițiativele legate de încropirea Micii Înțelegeri (1920) şi evenimentele din timpul conflagrației mondiale secunde. 
his dreams of greatness and imperial culture, Vasile Lupu, who hosted an ecumenic orthodox synod in Iassy, trying to stop the roman-catholic and calvinist propaganda inside Moldova together with the greatest theologians of his time. At his turn, Michael the Brave wanted, in the first period of his anti-Turkish military campaign (in the years 90 of the 16Ith century), to free the Balkans from the Ottoman domination. Closer, in the early 19th century, the idea of a confederation between the peoples from the lower Danube became visible in the political papers and projects of the small Romanian nobility (like the Federative Conspiration of Ioniță Tăutul).

With the coming of the German chancellor Otto von Bismarck's protegee, Charles I von Hohenzollern und Sigmaringen, on the Romanian principalities throne, the old project attended a revival, this time under Prussian protection. On the 20th of May, 1888, just six years after transforming the unified principalities into a Kingdom, Vasile Pogor, a valuable public personality, spoke about Charles I to his friend A. C. Cuza: "The German is much wiser than the country thinks. He suffers and keeps silent, following his plans in a wider prospective. /.../ Some people say that he dreams about founding a great Balkan state, in order to be its leader, and which would include into a confederation Bulgaria, Serbia, Romania etc."' The fact was accomplished just partially, at the time of the Balkan wars. Their peace was negociated with Romania as arbiter, in Bucharest, in 1913.

As Ioan Petru Culianu has remarqued - in the third chapter of his unpublished monographyn, The unknown Mircea Eliade (written between 1982 and 1983) -, in the Romanian inter-war period culture, there is a certain intellectual tradition of the 4th Rome. Reading N. Iorga, Radu Dragnea, Nae Ionescu and Nichifor Crainic, ideologists of genuine and original Romanian orthodoxy, followed by the disciples of the philosopher Nae Ionescu, such as Mircea Eliade, Cioran (with Tears and Saints/Lacrimi şi sfinți) and Constantin Noica (from a lot of the articles written in his younger years), I.-P. Culianu notices an attempt of putting together a common direction of thinking and acting in order to cover plural traditionalist directions: the orthodoxist nationalism of N. Iorga, the mistic "trăirism" of Nae Ionescu, the religiously orthodox coloured "gândirism" of Nichifor Crainic and also the spiritualist generationism from The Spiritual Itineray/ Itinerarul spiritual (1928) of Mircea Eliade (continued by Petre-Marcu Balş and the other authors of The White Lily Manifesto/ Manifestului Crinului Alb). Reconstructing briefly, but clearly, this structuring process of the dominant ideological mark of interwar Romania, Culianu went beneath the thinking of the schools from the time in a classical, monographic way, one at the time. Culianu remains, until now, the unique interpreter of that intellectual movement that subordinates to the imperial idea of orthodoxy taken from Byzance the different cultural traditionalist tendencies

3 A. C. Cuza, Însemnări din viaţă şi documente omeneşti, ed. de Marian Ştefan, Bucureşti, Ed. Oscar Print, 2012, p. 15. 
of the time. He offered a plausible explanation frame to the Romanian political dynamics, insuficiently explained by the Greater Romania project and that was not explainatory - leaving aside the momentary understanding between Hitler and Antonescu -, looking for the Romanian army at Stalingrad in the time of the second world war. "Let us go, brothers, to a terrible and soaring crusade, against the human rottenness, against all the dead ideals which suffocate our impulses and against all the forms which press on our mission" ${ }^{4}$, says Cioran in the Romania's metanoia/ Schimbarea la față a României. The term "crusade" does not leave room for any ambiguity. It concentrates in itself christian militantism, militarism, conquest, and also a substantial trace of fanaticism. Cioran's Romania was called to integrate, even if only destructuring previously. And the way for meeting this goal was, for the young thinker, excess ${ }^{5}$.

Also about the "crusade" in connection with the second world war, spoke general Dwight Eisenhower right in the title of his memories. Applying the concept, as a follow-up of the American memorialist, to WW2, and, mainly, to the warrior initiative of the Axis, we can better understand that the perception on the revolutionary initiatives from the second inter-war decade was that it tried, to destroy for good the existent democratic environment, seen as a failure, and to replace it with a new, totalitarian, order. It seems that even WW1 was not a valuable lesson for this type of politics. Two decades later, marshall Ion Antonescu was going to war again, participating in the German adventure on the eastern front not only for regaining Basarabia from the Soviets, but also for finishing with the slavic race and getting rid of Russian orthodoxy for a Romanian one ${ }^{6}$. The old project of a Latin orthodox domination, namely a Romanian one, in this part of Europe, was not fading even if the reality was pretty complex.

Putting the meditation of Emil Cioran from Romania's metanoia in the shadow of the ideological line that dreamed about a Romanian power in the Balkans and even more than that, in all the Eastern Europe, "between Berlin and Moscow",

4 Cioran, "Tentația politicului şi a jertfii", in Vremea, year VII, nr. 321, 14 January 1934, see Revelațiile durerii, ed. cit., p. 121.

5 "Pentru a înțelege spiritul Germaniei de astăzi, este absolut nevoie să iubeşti tot ceea ce este exagerat, tot ceea ce răsare dintr-o pasiune excesivă şi debordantă, să fii încântat de tot ceea ce este avânt irațional şi monumentalitate deconcertantă" /To understanding the spirit of Germany nowadays it is absolutely necessary to love the exaggerated, all that comes from an excessive and overflowing passion, to be enchanted by all that is irrational enthusiasm and disconcerting monumentality"/ (Emil Cioran, "Aspecte germane", în Vremea, an. VI, nr. 314, 19 noiembrie 1933, p. 9). "Dacă îmi place ceva la hitlerism este cultul iraționalului, exaltarea vitalității ca atare, expansiunea virilă de forțe, fără spirit critic, fără rezerve şi fără control” / If I like something about hitlerism is the cult of irrational, the exaltation of vitality as it is, the masculine expansion of forces, without critical spirit, without reserves and without control"/ (Emil Cioran, "Germania şi Franța sau iluzia păcii”, in Vremea, an. VI, nr. 318, Crăciun 1933).

6 Eduard Mezincescu, Mareşalul Antonescu şi catastrofa României, Bucharest, Ed. Artemis, 1993, pp. 51-53, 62-63, 139. 
allows one to align his work between the texts with a programmatic value for a certain Romanian expansionism comming from the Middle Ages, following the dream of an imperial legitimacy, which was manifesting itself as an imperialist modern fantasy, slightly grotesque for us. But not for young Cioran!

In Cioran's texts the integration of the eastern oecumene under Romanians - a dream mirrored later by the thinking of marshall Ion Antonescu - meant more than one thing. Without telling it expressly, he projected on to his own people the capacity and the ability to substitute itself, together with its orthodox vocation, to Moscow, the third Rome, becoming the centre of the eastern-christian religion from where the "light" was coming. But this type of mission was not to be done by the efforts of a "vegetable", passive, unclear in its plans. Therefore, the integration seen by Cioran also meant a moral and spiritual ressurection of the Romanians. He had in mind a real revolution. But "Națiunile mici nu pot face revoluții universale" /"Small nations cannot make universal revolutions"/ 7 . He thinks that, "O revoluţie trebuie să suprime un sistem general-valabil, existând, în forme diferite, în toate țările şi să întroneze altul, susceptibil de a fi primit pe întreg globul, indiferent de nivelul istoric al celorlalte națiuni” /“A revolution has to supress a generally accepted system that existed in different forms in all the countries and to install another one, susceptible of being accepted by the entire globe, no matter the historical level of the other nations"//. Localised "Între Berlin şi Moscova, România este silită să-şi creeze un drum propriu" /"Between Berlin and Moscow, Romania is forced to create its own way/ ${ }^{9}$. The problem is that "Orice revoluție națională este numai o treaptă /subl. E.C./. Ar putea spune cineva că fascismul şi hitlerismul sunt culmile istorice a două națiuni? Nu-mi vine a crede"/ "Any national revolution is only a step. Could one say that Fascism and Nazism are historical peaks of two nations? I can not believe it." $/ .{ }^{10}$

Because Romanians need a boost, even despite their will, the way of totalitarianism is required as for granted, as in the case of Cioran. "I conceive dictatorship as a permanent revolution / E.C. /."11, 'he says and: "In Romania only terror, brutality and endless anxiety could change something. All Romanians should be arrested and beaten, this being the only way for superficial people to make history ". ${ }^{12}$ Prudent, he thinks that "If the revolution of the nationalists does not bear fruit, they are not to blame, but the inherent flaws of our people". ${ }^{13}$

7 Ibidem, p. 167.

8 Ibidem, p. 167.

9 Ibidem, p. 229.

10 Ibidem, p. 168.

11 Cioran, Schimbarea la față a României, Bucharest, Ed. Humanitas, p. 191.

12 Cioran, letter to Petru Comarnescu, dated 27 December 1933, editet by Simona Cioculescu, in Manuscriptum, year XXIX, no. 1-2, 1998, p. 234.

13 Cioran, "În preajma dictaturii”, in Vremea, year X, no. 476, 21 February 1937, p. 3. 